\title{
Review of Miocene shallow marine and lacustrine depositional environments in Northern Croatia
}

\author{
Tomislav MALVIĆ
}

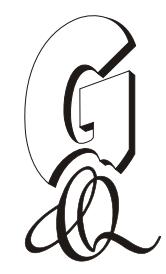

Malvić T. (2012) - Review of Miocene shallow marine and lacustrine depositional environments in Northern Croatia. Geol. Quart., 56 (3): 493-504, doi: 10.7306/gq.1035

\begin{abstract}
The Neogene and Quaternary depositional and structural characteristics of the southwestern Croatian Pannonian Basin System (CPBS) are unique within the Pannonian Basin System. Due to its position at the basin margin, the area was covered by shallow and partially isolated parts of the Pannonian Sea in the Badenian (Middle Miocene). Later, in the Pannonian and Pontian ages, the area contained several brackish lakes, the largest being Sava Lake and Drava Lake. Tectonic events, sedimentation and depositional mechanisms occurring during the Neogene in the CPBS have revealed that those areas can be considered as former shallow seas or lakes dominated by clastic sedimentation. Marine coarse-grained clastic sedimentation took place during the Badenian, with local sources of material and numerous alluvial fans developed during the first transtensional phase. In the Pannonian and Pontian (Late Miocene), sediments were deposited by turbidity currents from a single, distal material source located in the Eastern Alps during the second transtensional tectonic phase.
\end{abstract}

Tomislav Malvić, INA-Industry of Oil Plc., Šubićeva 29, 10000 Zagreb, Croatia, Faculty of Mining, Geology and Petroleum Engineering, University of Zagreb, e-mail: tomislav.malvic@ina.hr (recevied: February 22, 2012; accepted: June 05, 2012; first published online: August 22, 2012).

Key words: Pannonian Sea, Pannonian Lakes, Paratethys, Miocene, alluvial fans, turbidites.

\section{INTRODUCTION}

Sedimentation in brackish lakes is complex, depending mainly on the size and depth of the lakes, and the surrounding topography. In this case, narrow marine inlets and brackish palaeolakes in the Croatian region of the Pannonian Basin, as relics of the Middle Miocene Pannonian Sea of the Paratethys, defined the environments and transport directions.

The Croatian Pannonian Basin System (CPBS) within the overall Pannonian Basin System (PBS; Fig. 1) is an example of Neogene and Quaternary sedimentation and tectonics in a marginal basin contained within a larger basin system. Clastic sedimentation continued throughout the transition from a marine to a freshwater environment caused by a reduced depositional area (e.g., Royden, 1988; Velić, 2007; Malvić and Velić, 2011). Today the CPBS covers the entire southwestern-southern part of the PBS and is characterized by many features that can be recognized in other areas of the basin. Numerous hydrocarbon reservoirs have been discovered in many of these sequences, making it possible to carry out quality measurements of lithological and saturation properties (e.g., Velić et al., 2002,
2008, 2010; Malvić, 2003; Velić, 2007). The southwestern margin of the CPBS is characterized by a contact with the Dinarides (Fig. 1). This contact is marked by the Periadriatic-Vardar lineament and southern Sava Fault, a very deep fault zone that represents a regional border for Neogene sedimentation in the Pannonian Sea during the Badenian and Sarmatian, and later in the Sava Lake from the Pannonian to the end of the Pontian (Malvić and Velić, 2011). Several partially isolated Neogene depositional areas in the CPBS are surrounded by numerous inland and highland areas (e.g., Vrbanac, 2002; Malvić, 2003; Velić, 2007; Vrbanac et al., 2010). In addition, the syn-sedimentary Drava Fault divides the CPBS from the environments of the Zala Basin and the Great Hungarian Plain in Hungary, such that the CPBS was relatively isolated in the PBS. Moreover, almost all present-day mountains in contemporary Northern Croatia (e.g., Kalnik, Moslavačka gora, Papuk, Psunj shown on Figs. 2 and 3) represented the characteristic features of the CPBS during the Neogene. Those mountains comprised uplifted palaeorelief throughout the Neogene, very often above sea or lake level, representing palaeo-mountains the positions of which defined the shapes of several elongated depressions whose outlines are clearly parallel to the 


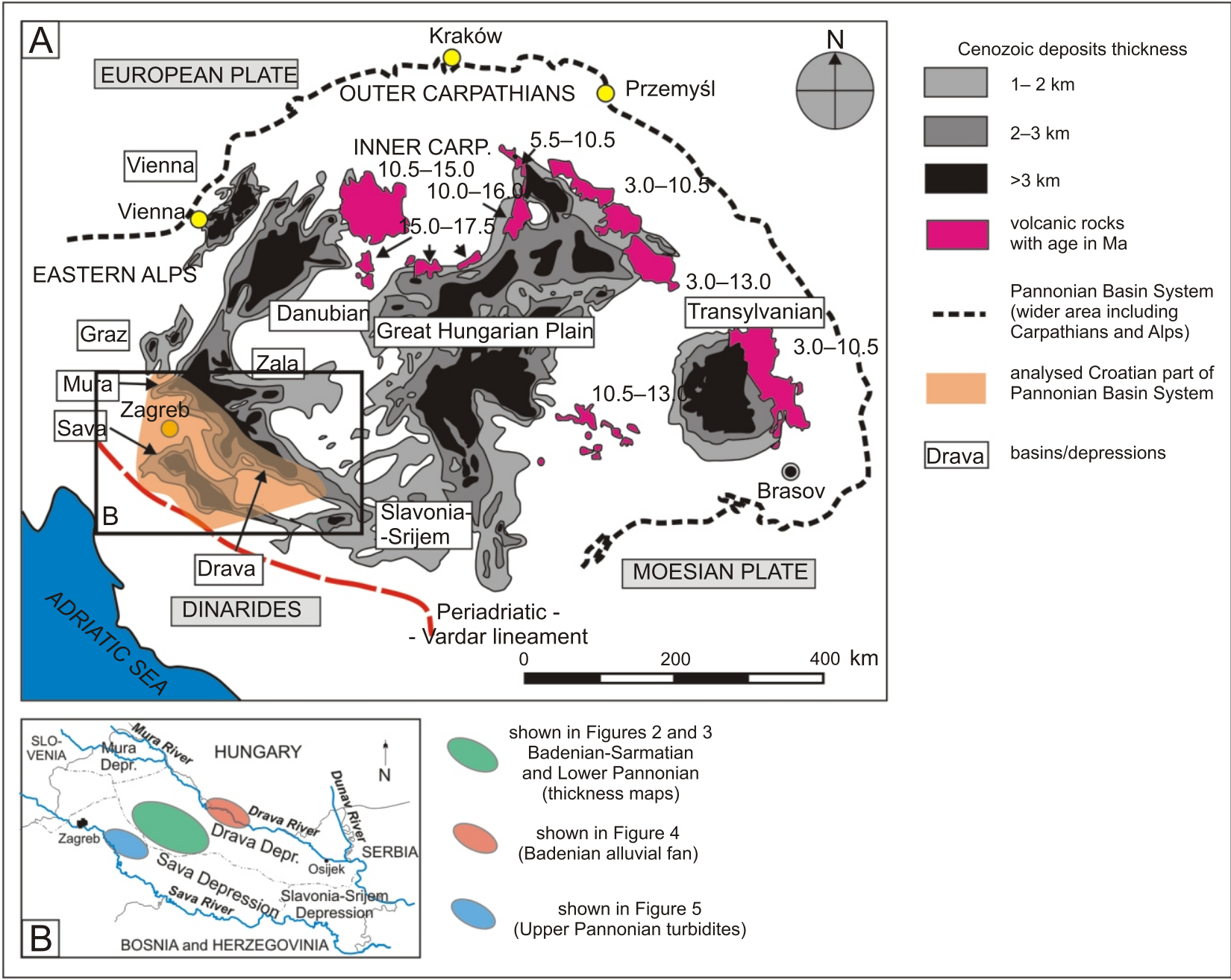

Fig. 1A - geotectonic units of the Pannonian Basin System in the Croatian and B - areas studied (modified after Royden, 1988)

southwestern margin of the PBS. According to Malvić and Velić (2011) the development of the CPBS comprised two episodes of sedimentation over long periods in substantially different depositional environments. The first of these included a set of small alluvial fans connected by local uplifts during the Badenian; the second took place from the Late Pannonian to the Early Pontian and was composed of numerous turbiditic episodes in lacustrine environments. The main properties of those two environments into the CPBS can be presented as models of sedimentation in the generally shallow sea or lake environments that were filled mostly by clastic deposits, as illustrated here using examples of sedimentation during the Miocene in Northern Croatia.

\section{TRANSPRESSIONAL AND TRANSTENSIONAL EVENTS IN THE CPBS}

The oldest tectonic displacements have been dated to the Paleozoic and Mesozoic orogenies (Malvić and Velić, 2010); however, large volumes of Mesozoic rocks were eroded in the Paleogene during uplift of the Adriatic Carbonate Platform to the south (Royden, 1988; Yilmaz et al., 1996). As a result, during the Early Neogene most of the CPBS was part of the Euro- pean plate, which subsequently began to spread due to increased heat flux from the Earth's mantle. Royden (1988) and Rögl (1996, 1998) documented the ages of different Miocene episodes in the Pannonian and established a scale for categorizing tectonic and sedimentation cycles, describing the Badenian-Pliocene interval as the time of greatest sediment deposition. Deposits older than Badenian are found only sporadically, and have fluvial or lacustrine origin. The Pliocene and Quaternary are mostly characterized by inland and restricted freshwater deposits, influenced by tectonic inversion (e.g., Velić, 2007; Malvić and Velić, 2010, 2011).

The main extension and marine transgression in the CPBS (Ćorić et al., 2009) commenced and peaked in the Badenian (16.4-13.0 Ma: time span according to Haq and Eysinga, 1998), with regional extensional tectonic activity across the entire PBS causing uplift of the Apennines and the Dinarides (e.g., Royden, 1988; Yilmaz et al., 1996). In the CPBS this is termed the first transtensional phase (Malvić and Velić, 2011) in which strike-slip tectonics was the main mechanism of structural development forming several large mountain islands (Vrbanac, 2002). The sources of clastic sediments during the Badenian and Sarmatian were either siliciclastic basement rocks or Badenian carbonates from corallinaceaen and bryozoan reefs (Malvić, 1998, 2003), and were mainly deposited as 


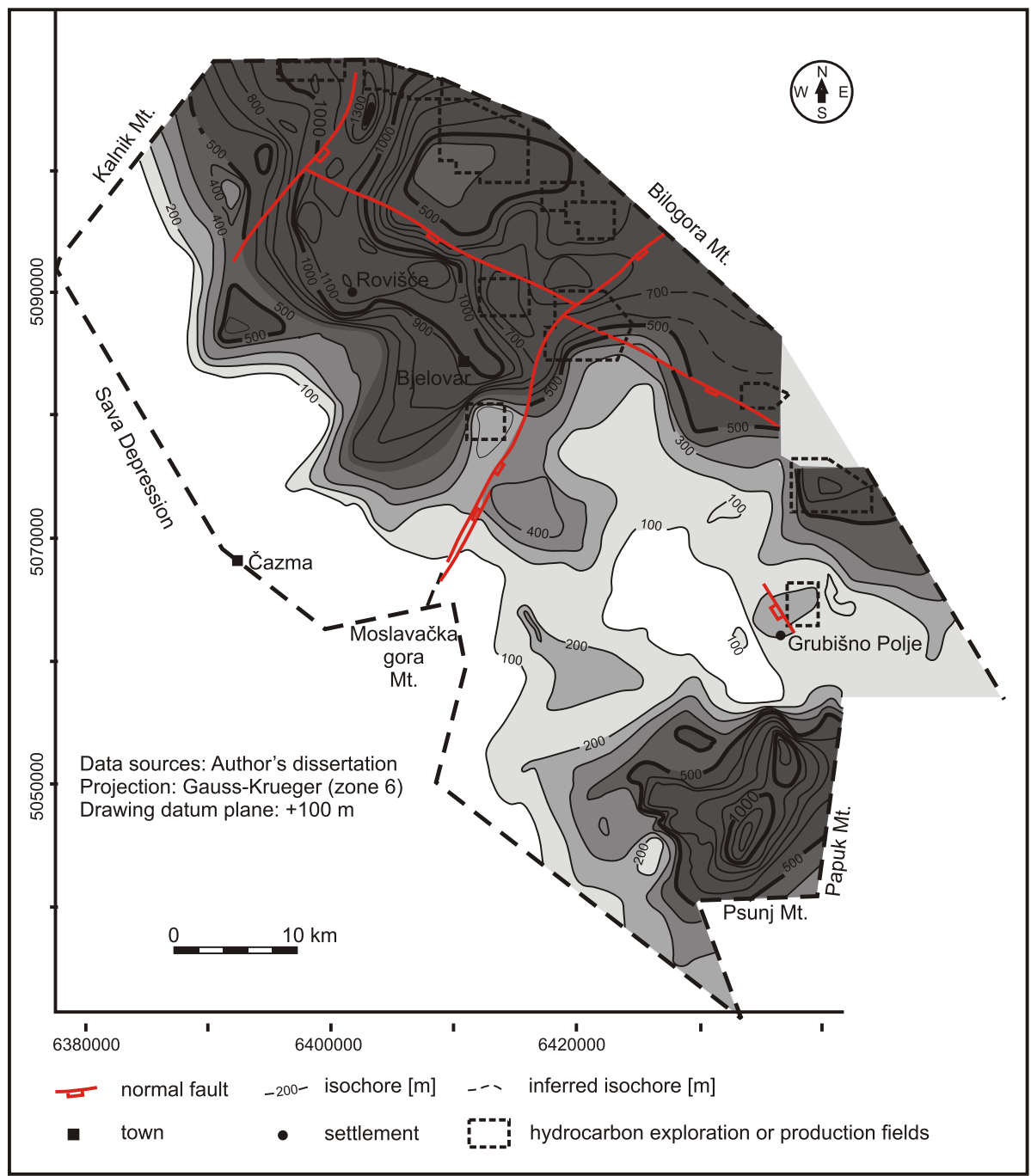

Fig. 2. Thickness map of Early Pannonian strata in the Bjelovar Subdepression (modified from Malvić, 2011)

alluvial fans. Most Upper Badenian strata consist of fine-grained sandstones, siltstones and limestones overlain by calcitic marlstones (e.g., Pavelić, 2002), indicating reduced salinity and depth. The Sarmatian (13.0-11.5 Ma: Haq and Eysinga, 1998) was the interval of the first transpressional phase (Malvić and Velić, 2011), which was accompanied by overall regression typical of the Central Paratethys (e.g., Rögl and Steininger, 1984; Kovač et al., 1997; Pavelić, 2001; Vrsaljko et al., 2006). The prominence of alluvial fans significantly decreased, and a fall in sea level and reduced salinity created a brackish environment with dominant pelitic sedimentation (e.g., Malvić, 2006). These conditions continued virtually unchanged until the Early Pannonian (11.5-9.3 Ma: Haq and Eysinga, 1998), which marks the transition between the initial transpression and subsequent transtension (e.g., Malvić and Velić, 2011). The Central Paratethys disintegrated into smaller brackish basins and depressions (e.g., Rögl, 1998). Evidence of the transpression and later transtension can be observed on thickness maps of the Bjelovar Subdepression (Figs. 2 and 3). The Badenian and Sarmatian map (Fig. 3; Malvić, 2011) nicely shows a large regional unconformity along the eastern border, Psunj Mountain (the direct result of transpressional uplifting), due to the Sarmatian or first transpression and consequently considerable erosion in the east. By contrast, deposits dating from the Early Pannonian (Fig. 2; Malvić, 2011) cover the entire subdepression and also show a maximum thickness more than twice that of the Badenian-Sarmatian interval ( $>1200 \mathrm{~m} v s .500 \mathrm{~m}$, Fig. 2 vs. Fig. 3). The areas with maximum Badenian-Sarmatian thickness were not eroded as in the eastern part (Fig. 3). The significant volumes of total strata shown in Figure 2 clearly indicated that the Lower Pannonian thickness maps also show the interval when the second transtensional phase started. This is also earlier than across most of the CPBS, where the lithologies and thickness belonging to the second transtensional phase can be clearly observed even in the Upper Pannonian.

According to Malvić and Velić (2011) the second transtensional phase began in the Late Pannonian (9.3-7.1 Ma: Haq and Eysinga, 1998) and continued throughout the Early Pontian (7.1-5.6 Ma: Haq and Eysinga, 1998). Successive turbidite events were the main depositional mechanisms in the Late Miocene (Vrbanac, 2002; Vrbanac et al., 2010; Malvić and Velić, 2011), when clastics were transported from the Eastern Alps to the CPBS by turbidity currents initiated by 


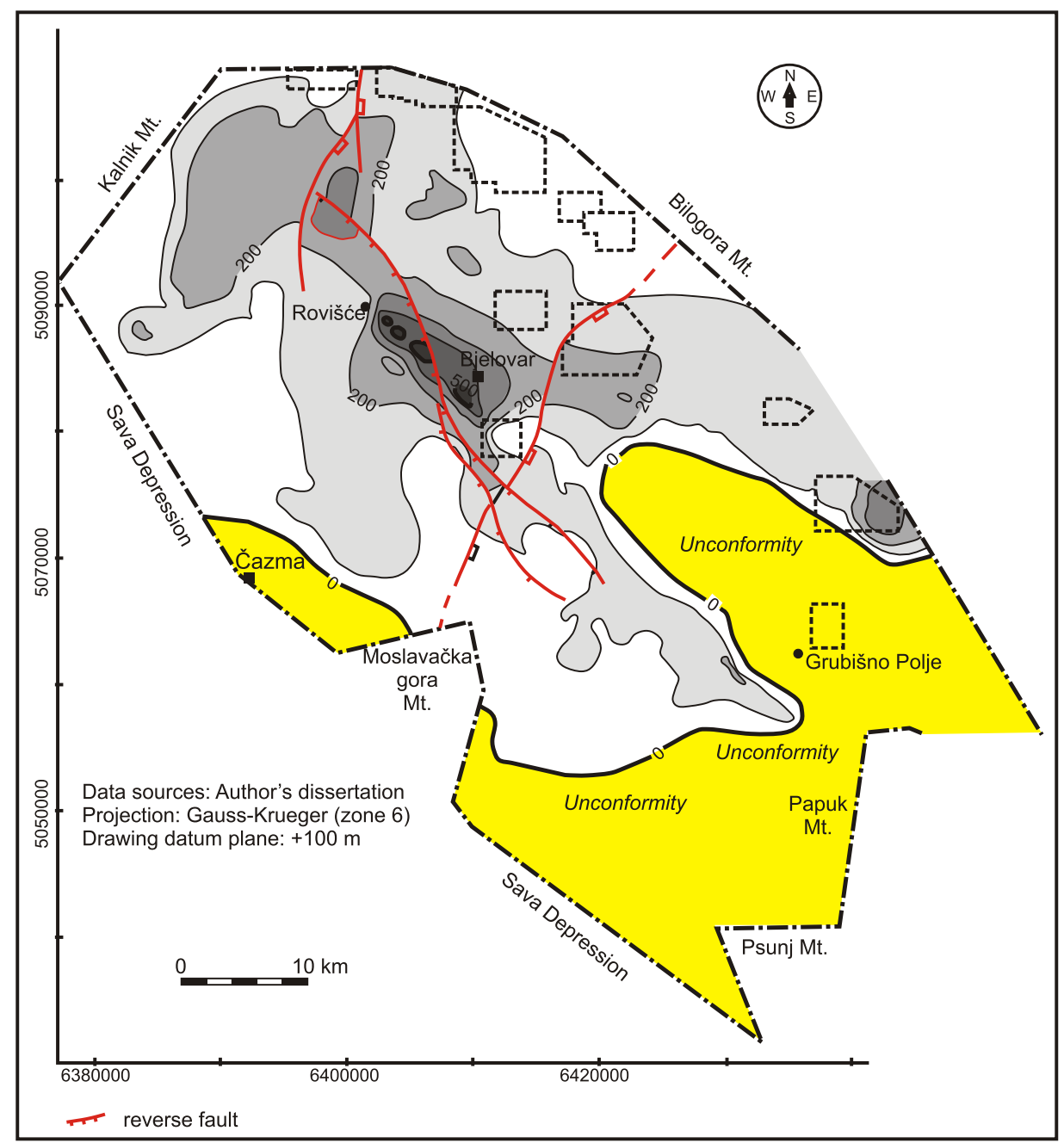

Fig. 3. Thickness map of Badenian and Sarmatian strata in the Bjelovar Subdepression (modified from Malvić, 2011)

Other explanations as in Figure 2

ramp-faulting activity. Each depositional episode moved clastics over tens of kilometres to deposit them adjacent to the next tectonic ramp and carried sediments to structurally determined deposition centres in the Mura, Sava, Drava and Slavonia-Srijem depressions (Fig. 1). Each period of turbidite activity was followed by pelitic sedimentation in lacustrine environments, resulting in a regular alternating sequence of sandstone and marlstone lithofacies through most of the Pannonian and Pontian (e.g., Vrbanac et al., 2010).

The Late Pontian, Pliocene (5.6-2.6 Ma: time span according Malvić and Velić, 2011) and Quaternary (2.6-0.0 Ma: Malvić and Velić, 2011) were intervals of the second transpressional phase, during which the most of negative (mainly flower) structures were uplifted, in many cases forming anticlinal hydrocarbon traps. The subaqueous environment was greatly reduced, being only sporadically lacustrine and evolving into Quaternary marshes, river alluvia and predominantly continental loess. The overall durations of the regional transtensional and transpressional phases in the CPBS are given in Figure 4.

\section{DEPOSITIONAL MEGACYCLES AND LITHOFACIES IN THE MARINE AND LAKE ENVIRONMENTS ANALYSED (CPBS)}

Neogene and Quaternary deposits in the CPBS are grouped into three megacycles (Velić et al. 2002; Velić, 2007), each with its characteristic depositional lithofacies, environment and chronostratigraphic age, mainly defined from borehole cores in hydrocarbon exploration and production areas. The rock properties in each megacycle are recognizable in seismic sections, well cores, logs and outcrops (Blašković et al., 1984). Generally, the total thicknesses of the megacycles are 500-1500 $\mathrm{m}$ at the margins of depressions, up to $3500 \mathrm{~m}$ in central areas of the Slavonia-Srijem Depression, $5500 \mathrm{~m}$ in the Sava and Mura depressions, and approaching $7000 \mathrm{~m}$ in the Drava Depression (Velić, 2007). Each megacycle comprises the rocks deposited during one supercycle of relative sea level change, characterized by a gradual rise in sea level followed by a relatively abrupt fall. All megacycles are lithologically different, a result of different transtensional and transpressional phases (Fig. 4) accompanied 


\section{Million of years in the past [Ma]}

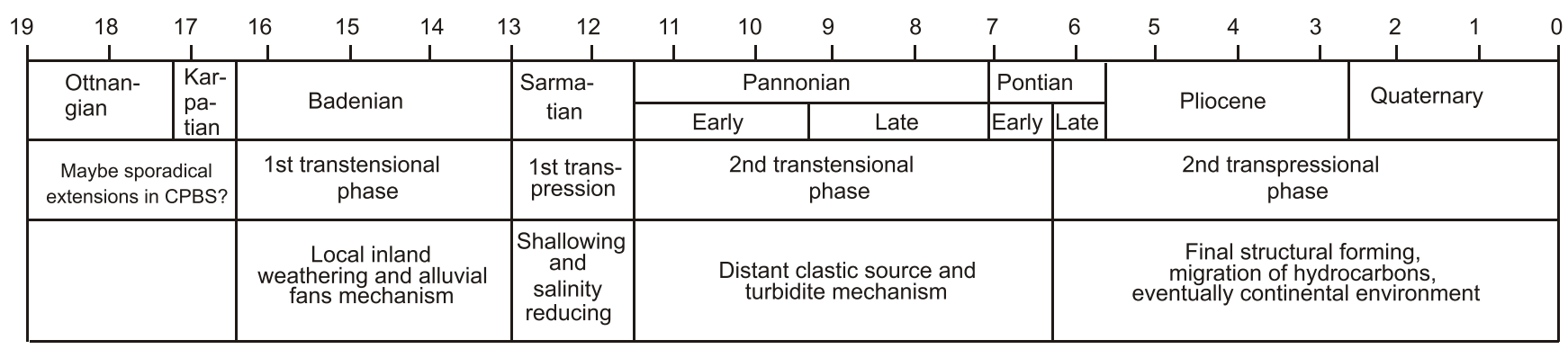

Fig. 4. Time-scales of the main tectonic and depositional events in the Neogene and Quaternary in the CPBS (from Malvić and Velić, 2011)

by deposition onto different basin topographies at times of different eustatic levels. Due to the similarity between the depositional environments in depressions throughout Croatia, correlation between megacycles (Velić et al., 2002) and systematically dated lithostratigraphic units (e.g., Malvić, 2003) can be established, as shown for the Drava Depression (Fig. 5).

The first (oldest) megacycle lasted for most of the Badenian (3.4 Ma), which can extended when local, non-marine deposits of the Lower Miocene are included. It is characterized by mostly coarse-grained clastics (breccia, conglomerates or sandstones) in the older parts, and fine-grained and pelitic clastics (clays, marls, calcitic marls, sandy and clayey marls with tuff intercalations) or limestones (Lithothamnium) in chronostratigraphically younger areas. The thickness of such deposits changes dramatically over short distances: for example, in the Sava and Drava depressions it differs by more than $2000 \mathrm{~m}$ within three or four kilometres. The pelitic deposits have very often proven to be hydrocarbon source rocks rich in organic matter (e.g., Troskot-Čorbić et al., 2009).

The second megacycle was deposited during the Pannonian and Pontian, when sandstones, siltstones and marls were deposited over a period of approximately $5.9 \mathrm{Ma}$ (Velić et al., 2002). A brackish lacustrine environment existed throughout the Pannonian, becoming a freshwater environment in the Pontian (e.g., Velić, 2007). Lakes were mostly up to $200 \mathrm{~m}$ deep (Vrbanac et al., 2010), with approximately equal rates of sedimentation and subsidence. The present-day total thickness of Late Miocene deposits is more than $4000 \mathrm{~m}$ in the deepest parts of the Drava Depression (Velić et al., 2002).

The youngest is the third megacycle of the Pliocene and Quaternary, which lasted approximately 5.6 Ma (Velić et al., 2002). It consists of alternating poorly consolidated sandstones and soft clays, locally containing lignite. Clayey limestones, marls and fine-grained sandstones were succeded by gravels, loess and silts. The deposits are more than $1500 \mathrm{~m}$ thick in the Sava Depression and $2200 \mathrm{~m}$ in the Drava Depression (Velić et al., 2002), and are mainly of continental facies.

\section{DEPOSITIONAL MECHANISMS IN THE MARINE AND LAKE ENVIRONMENTS ANALYSED (CPBS)}

The depositional systems inferred throughout the analysed CPBS were produced by two main mechanisms, which to- gether transported the bulk of the clastic materials and formed different lithofacies. The age and style of such mechanisms can be deduced from, for example, cross-sections of the Kloštar Field, which is one of the best explored structures in the Sava Depression (Velić et al., 2011). The first depositional mechanism was active in the Badenian and can be correlated with the first transtensional phase (i.e. third megacycle). The second mechanism was active from the Late Pannonian to the Early Pontian and can be correlated with the second transtensional phase and second megacycle.

\section{ALLUVIAL FAN-DOMINATED DEPOSITIONAL MECHANISM IN THE BADENIAN}

Badenian strata are commonly observed in the CPBS to be medium- to coarse-grained rocks, often with proven hydrocarbon reservoirs having high average primary porosities (more than 10\%). These were deposited during the first Neogene transtensional phase in the Badenian when all of Northern Croatia was a marine environment (e.g., Vrbanac, 1996; Rögl, 1996, 1998; Ćorić et al., 2009; Malvić and Velić, 2011). However, the faulted and weathered palaeorelief of the Paleozoic and Mesozoic basement resulted in significantly different depths (e.g., Malvić, 2003, 2011). Present-day Neogene outcrops on mountains such as the Papuk or Psunj Mts. show that large parts of what are now mountains in northern Croatia were islands in the Badenian and therefore sources of inland weathering through alluvial fans and short-transport debris flows. Also, sub-sea palaeorelief (especially the so-called "buried hills") was faulted and cataclased (as in the Molve structure; Malvić and Velić, 2010), resulted in deposited of breccias and conglomerates. Such breccias, derived from pre-Badenian palaeorelief and Badenian carbonates, can locally reach thicknesses of tens of metres, as in the Beničanci structure in the eastern Drava Depression (Tišljar, 1993). Badenian carbonate coarse-grained detritus was derived from erosion of numerous reef colonies of Corallinaceae and Bryozoa in shallow Central Paratethys.

The Badenian palaeo-sea depths in the CPBS have been approximated from fossils collected from numerous borehole cores. A large fossil database from the Bjelovar Subdepression had been published by Malvić (2003). The species listed are generally found in the CPBS as a whole. The predominantly shallow marine environments in the CPBS during the Badenian 


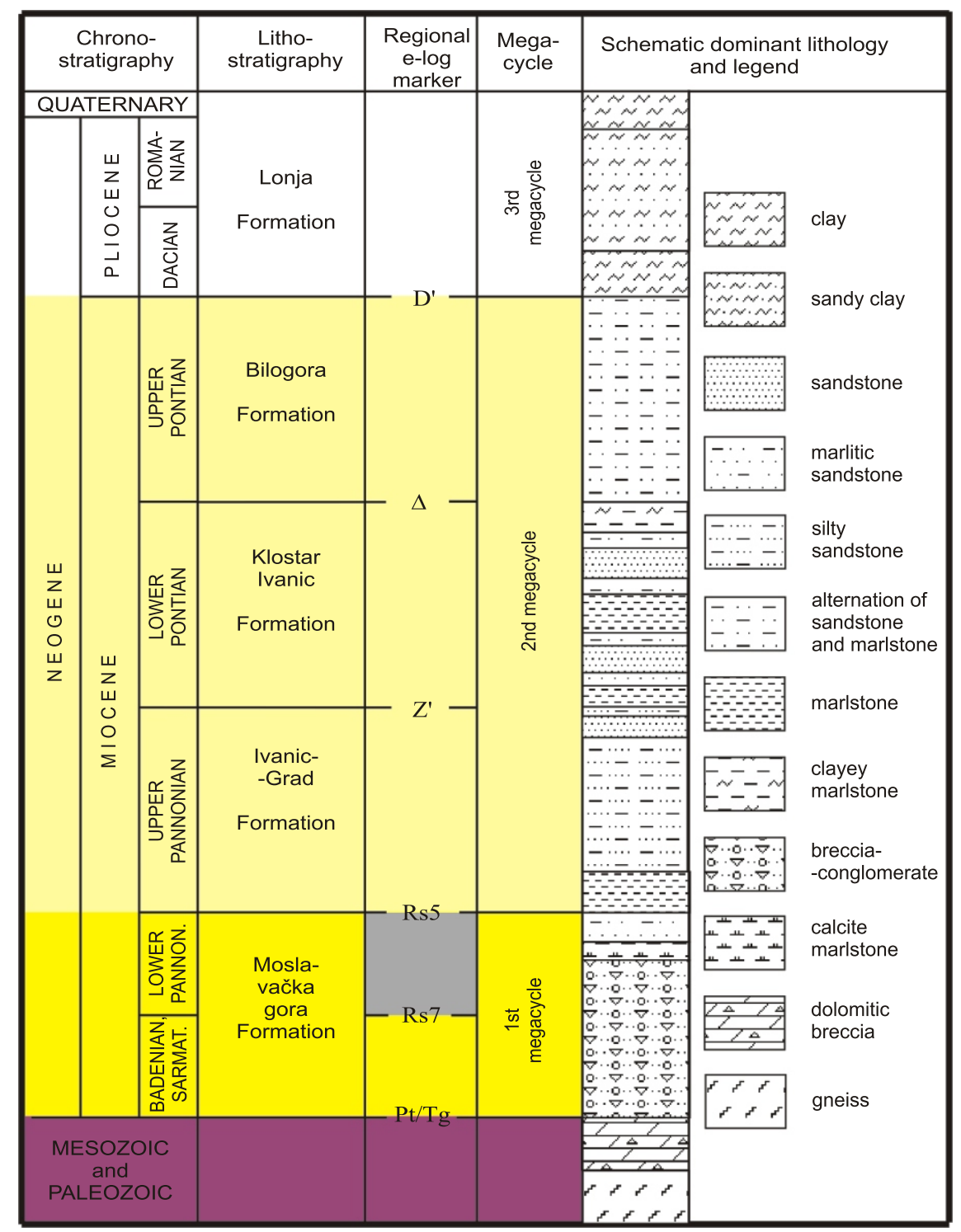

Fig. 5. Correlation between lithostratigraphic formation and depositional megacycles in the Drava Depression

Vertical scale is not show thickness of units, then each formation has the equal size

are documented by the presence of fossil benthic foraminifera and species of red and green algae. Also, deep marine areas are indicated by the presence of plankton foraminifera (Table 1).

A reconstruction of the Badenian depositional environment, indirectly using maps of average porosity for lithological description, is shown in Figure 6. Typical alluvial environments were distributed over relatively small distances of a few kilometres (e.g., Malvić, 1998), and migrated across space over time. The coarsest sediments (breccias, conglomerates and sandstones) were deposited in the upper fan, often rich in carbonate detritus derived from weathered and cataclased reefs. Carbonate clasts are mostly found in the upper fan, mixed with siliciclastic detritus from the hinterland, because those were shallow, littoral, shore-line zones, with abundant carbonate reefs. The middle fan mainly comprised medium-grained sandstones. The lower fan consisted mainly of fine-grained sandstones and siltstones deposited in depths of up to $100 \mathrm{~m}$.
The coarse-grained alluvial fan deposits have significant primary porosity (regularly more than $10 \%$ ), whereas the porosity of distal facies is usually less than 3\% (Fig. 6C). Generally, throughout the CPBS, these strata, characteristic of the Lower and Middle Badenian, are overlain by calcite-rich pelitic (marine) deposits of the Upper Badenian.

\section{TURBIDITIC DEPOSITIONAL MECHANISMS IN THE PANNONIAN AND EARLY PONTIAN}

In the Late Pannonian and Early Pontian (9.3-5.6 Ma), and even locally in the Early Pannonian, depressions in the CPBS were elongated brackish lakes filled with turbidites that interrupted basin pelitic sedimentation (Malvić and Velić, 2011). In fact, during the Late Miocene the entire PBS was an open lake system, with active inflows and outflows (e.g., Bérczi et al., 1988). 
Characteristic fossil content for Badenian shallow and deep marine environments in the Bjelovar Subdepression (data are taken from Malvić, 2003)

\begin{tabular}{|c|c|}
\hline \multicolumn{2}{|c|}{ Badenian } \\
\hline Shallow marine environment & Deep marine (few hundred metres) \\
\hline Benthic foraminifera species & Plankton foraminifera species \\
\hline $\begin{array}{l}\text { Amphistegina spp. - e.g., A. lesonii (d`Orb.); Bolivina spp.; Cibicides } \\
\text { spp. - e.g., C. uvigerianus (d`Orb.); Elphidium spp. - e.g., E. crispum } \\
\text { (Linné), E. macellum (Fichtel and Moll); Gypsina spp.; Heterolepa } \\
\text { horidiugeri (Brady); Heterostegina spp.; Lenticulina spp. - e.g., } \\
\text { L. cultrata (Montfort); Melania spp. - e.g., M. soldani (d'Orb.); } \\
\text { Miliolidae spp.; Uvigerina spp. and Textularia spp. }\end{array}$ & \multirow{5}{*}{$\begin{array}{l}\text { Globigerina spp. - e.g., G. bulloides (d'Orb.), G. concina (Reuss), } \\
\text { G. nephenthes (Todd), G. praebulloides (Blow); Globigerinoides } \\
\text { trilobus (Reuss), G. irregularis (LeRoy), G. bisphaerium (Todd); } \\
\text { Globorotalia obesa (Bolli); Orbulina universa (d'Orb.), O. bilobatc } \\
\text { (d'Orb.); Praeorbulina transitoria (Blow) and P. glomerosa (Blow), }\end{array}$} \\
\hline$\underline{\text { Red algae species }}$ & \\
\hline $\begin{array}{l}\text { Rhodophyta, fam. Corallinaceae, Lithothamnion spp. } \\
\text { and Lithophyllum spp. }\end{array}$ & \\
\hline Green algae species & \\
\hline Botrycoccus braunii (Kützing) & \\
\hline
\end{tabular}

Specific characteristics of the CPBS were (1) the main clastic source areas located to the distant north-east, (2) a turbiditic transport mechanism along the deepest lake floor, and (3) an absence of delta and prodelta environments (e.g., Vrbanac et al., 2010; Malvić and Velić, 2011). Some new work (e.g., Novak Zelenika et al., 2010; Novak Zelenika and Malvić, 2011) reconstructed the activity of smaller alluvial fans on the margins (hinterlands) of Pannonian and Pontian lakes into the CPBS. However, this source of clastic detritus, was of much smaller volume than those brought by turbidites. That Late Miocene lacustrine phase of the CPBS was the result of the division of a previously single Badenian and Sarmatian marine depositional area into several large lakes. The Late Miocene Sava Lake, for example, measured about $100 \times 25 \mathrm{~km}$.

The relocation of the sediment source to the Eastern Alps in the distant north-east altered the transport mechanism drastically from local alluvial fans to a regional turbidite mechanism with relocation of detritus on a scale of several hundred kilometres. Such turbidites were continually redeposited in the Mura Depression in the far north-west of the CPBS, and were the main source of medium-grained sandstones and silts (Bouma intervals $\mathrm{Tb}-\mathrm{Td}$ ) deposited farther to the east into other CPBS depressions. The turbiditic sandstone/siltstone sequences from one depositional phase may be up to several hundred metres in thickness (e.g., Malvić et al., 2005). In the "calm", non-turbidite periods, background basin sedimentation of silts and dominantly muds took place.

Turbiditic deposits are distinguished by the presence of several lithofacies recognized from e-logs and drill cores, as described by Vrbanac et al. (2010). Selection of those lithofacies was based on works of Bouma $(1962,1972)$, classical concept of palaeofans presented by Mutti and Ricci Lucchi (1972), and characteristic associations of turbidite facies, resulting from the turbiditic mechanism of deposition, that are widely used to interpret environment of deposition in ancient submarine settings (e.g., Mutti and Ricci Lucchi, 1972; Walker, 1978; Shanmugam and Moiola, 1985). However, as Shanmugam et al. (1985) wrote, this is valid assumption only assuming that "... (1) each specific subenvironment of a submarine fan is always associated with the same characteristic depositional processes, (2) these depositional processes remain constant through time in this subenvironment, and (3) all submarine fans develop identical facies in identical subenvironments within each fan". Also, they emphasised one important characteristic of the pelitic lithofacies. Such hemipelagic sediments, dominantly mud, can be also created in ancient submarine fan channels and surrounding plains by turbidites. These may be difficult distinguish from lithologically same hemipelagic sediments deposited the over basin plain.

The classification of Vrbanac et al. (2010) is here considered as the most appropriate for the CPBS. It included four lithofacies. The first, with the greatest hydrocarbon reservoir potential, is the turbidite channel-fill facies association, consisting of mostly thickly bedded sandstones deposited along the channel axis. The number of marl layers increases toward the channel margins, where the basin plain sandstones are thinner and contain more fine-grained content. The next lithofacies is the turbiditic overbank-levee association, where the lower part is composed of laminated sandstones, siltstones and marls overlain by sandstone layers. Deposition occurred outside the distributary channels where the turbidity currents were significantly weaker, producing overbank-levee, fringe and channel bank deposits. Then, towards the basin plain the lateral or distal turbidite facies association occurs, consisting of a regular alternation of very thin (laminated), thin and medium-thick sandstone beds that make a transition into siltstones and marls; in this association, erosion on bedding planes is almost completely absent. The last lithofacies is a massive marl facies association, dominated by massive marls with rare intercalations of siltstone or sandstone laminae. This lithofacies was continually deposited in marginal areas or areas outside the range of turbidites.

The greatest gross thickness and lithofacies diversity is observed in the central regions of depressions where the largest accommodation space was available. Most of the siliciclastic detritus reflects Alpine mineral associations (Šćavničar, 1979). This was transported from time to time over an interval on the scale of $10^{5}-10^{6}$ years, during which several redeposition events occurred, along with the deposition of coarser detritus in the deepest locations (e.g., Malvić and Velić, 2011). From the 


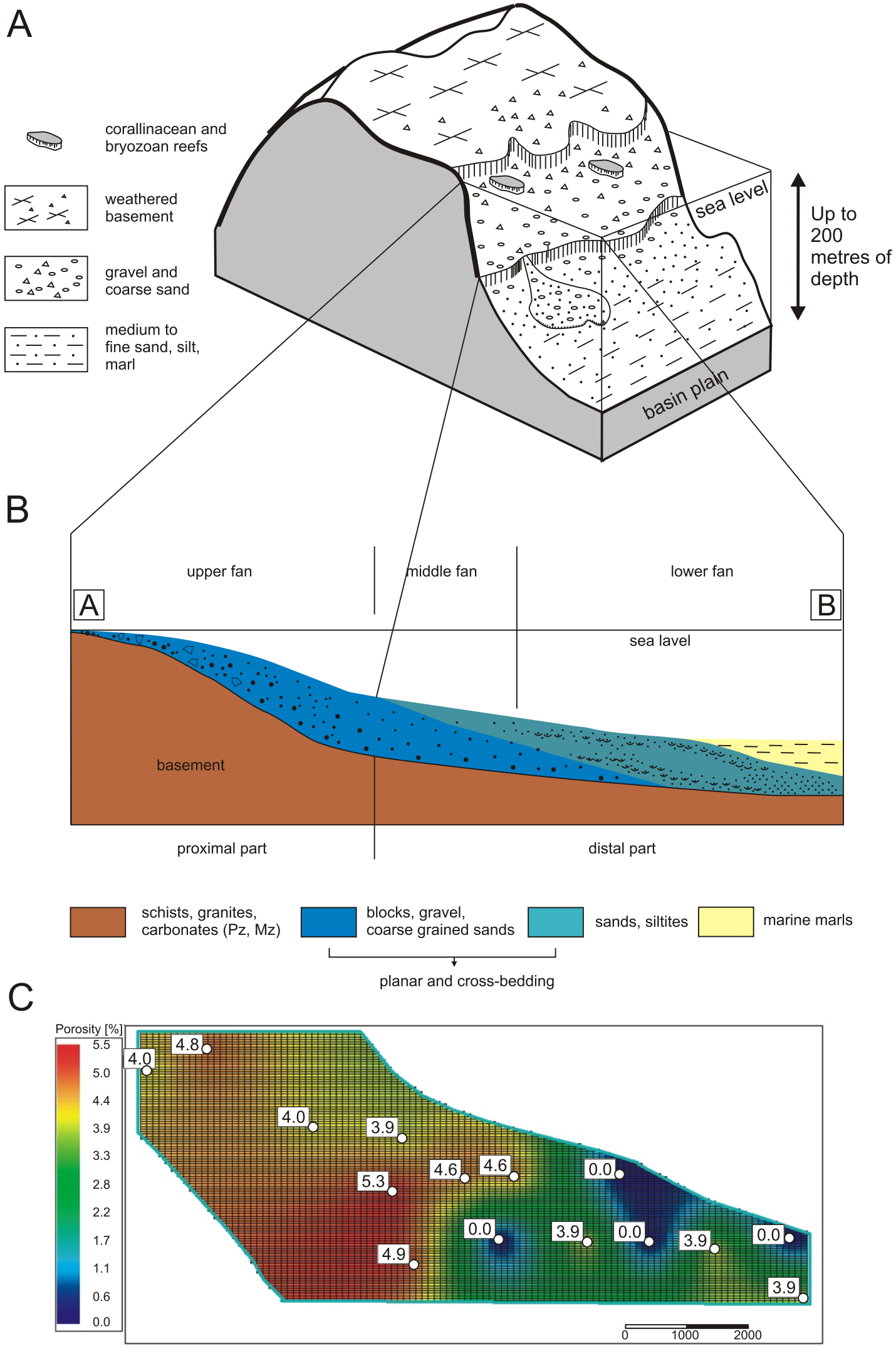

Fig. 6. Typical alluvial fan and lithofacies distribution in a shallow marine environment for the Drava Depression

A - typical uplifted Paleozoic or Mesozoic basement structure; B - schematic section along alluvial fan formed at A; reconstruction is based on results obtained mostly on the Stari Gradac-Barcs Nyugat structure within this depression (after Malvić, 1998, 2003, 2006; Malvić and Velić, 2011); C - distribution of porosity in typical alluvial fan environment of Badenian age in the Drava Depression 


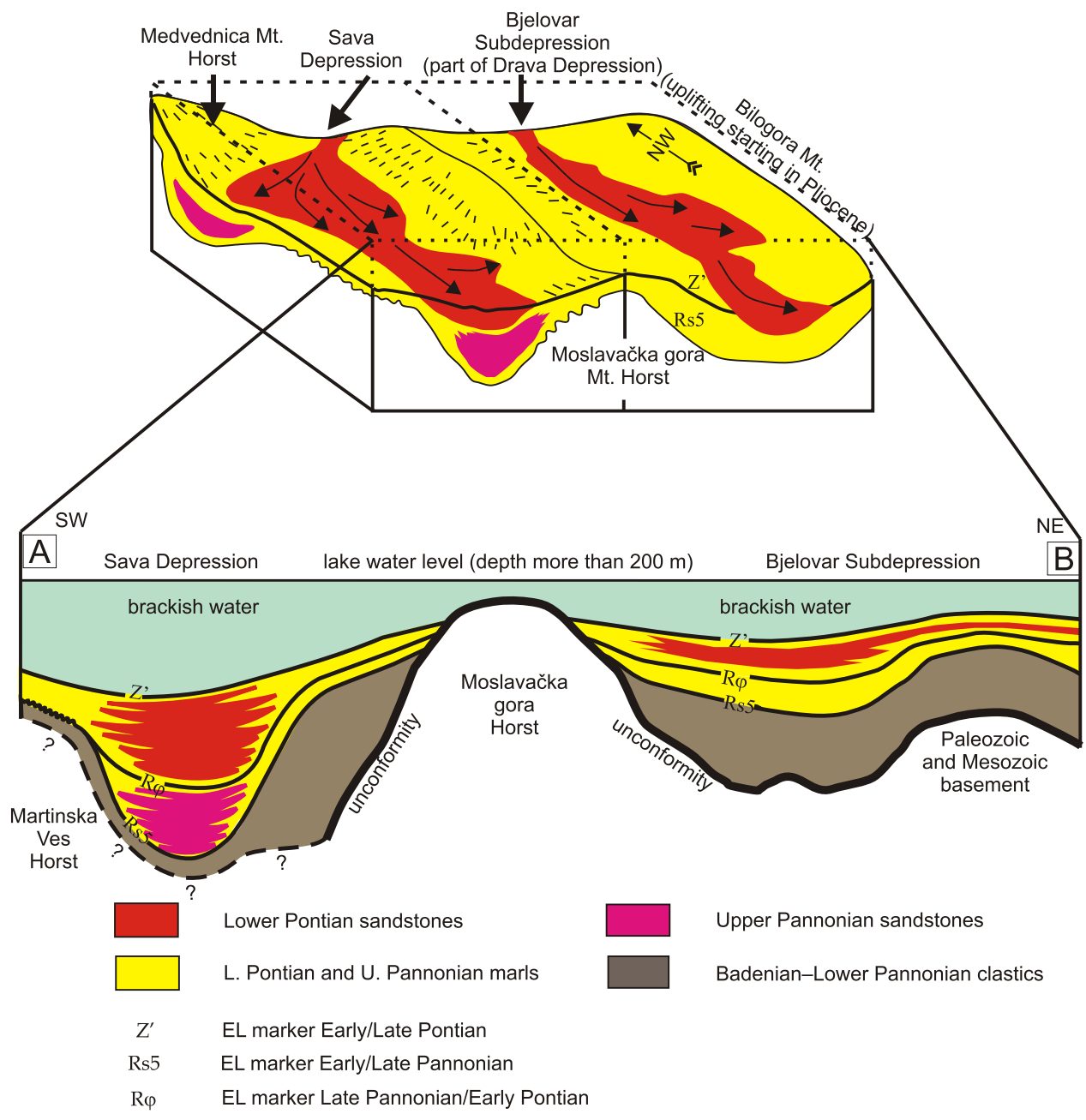

Fig. 7. Schematic palaeogeographic situation at the boundary between the Sava and the Bjelovar Subdepression (as part of the Drava Depression) at the end of the Late Pannonian (compiled after Vrbanac et al., 2010; Malvić and Velić, 2011)

Mura Depression in the west (Fig. 1), sediment that had accumulated on regional structural ramps was relocated by recurrent regional faulting events (Malvić and Velić, 2011) and transported to the Drava and Sava depressions (Fig. 7) as well as the Slavonia-Srijem Depression. Turbidite directions in particular depressions can be recognized from the geometry of the sandstone bodies (e.g., Novak Zelenika and Malvić, 2011). Generally, turbidity currents approached depositional areas from the north-west. However, locally, as in the Sava Depression, especially in the Early Pontian, currents also entered from the north (Vrbanac et al., 2010) or even the north-east (Hernitz and Jurak, 1973) as a result of luplifted palaeorelief. During a period of turbidite inactivity, "normal" pelitic basin sedimentation resulted in the deposition of lacustrine marls.

The Sava Depression, which defines the southwestern boundary of the entire PBS, striking between the Psunj and Prosara Mountains (Blašković, 1982), was the pinching-out zone for all turbidites. Generally, Late Pannonian and Early Pontian sedimentation resulted in regularly alternating sandstones and marls in depocentres, with predominantly marlitic and sandy marlitic lithofacies at the margins (e.g., Velić, 2007; Vrbanac et al., 2010).
The shallow lake environment in the Pannonian and Pontian stages (e.g., Velić, 2007; Vrbanac et al., 2010) was changing from brackish to fresh water (e.g., Malvić and Velić, 2011). In the Late Pannonian, fossil sporomorphs (although rarely found due to turbiditic erosion of basal sediments) and the presence of type III kerogens (Lučić et al., 1995) are strongly indicative of a shallow environment.

The final structural event (giving rise mostly to anticlines and anticlinoriums) occurred during the second transpressional phase (Table 1), i.e. from the Late Pontian to the Quaternary. Such examples have been described, e.g., for the Molve (Malvić and Velić, 2010) and Kloštar (Velić et al., 2010) structures. The most prominent result of the second transpressional phase was the uplift of Bilogora Mountain, which divided the Drava Depression and the Bjelovar Subdepression (Fig. 7) into two regional geotectonic units.

\section{CONCLUSIONS}

The depositional and structural evolution of Neogene and Quaternary deposits in the CPBS encompassed two 
transpressional and two transtensional regional phases. In the Badenian and Sarmatian, the CPBS was part of the Pannonian Sea. Later, in the Pannonian and Pontian, the sea transformed into a series of lakes, of which Sava and Drava lakes were the largest. However, for the entire Neogene, it was a shallow water environment where the depth was rarely deeper than 200 metres, as shown from fossil content, kerogen type and palaeogeographic maps.

The Badenian (Middle Miocene) was characterized by local detritus sources eroded from palaeo-mountains in the CPBS above sea level, which was transported to form alluvial fans comprising mainly coarse-grained detritus along the shoreline, especially in the shallow strike-slip structures. The detritus was both siliciclastic and carbonate. Strike-slip structures were also filled with tectonic breccia as a consequence of strong Badenian transtensional tectonic activity along entire CPBS.

The Pannonian and Early Pontian had been characterised by lithofacies resulted from numerous turbidity currents, which brought detritus from as far as Eastern Alps, re-deposited several times before it reached depositional centres in the form of depressions of the CPBS. The main detritus was sand- and silt- sized, and depositional events interrupted deposition of basinal (generally hemipelagic) muds.

The two depositional mechanisms (Badenian during the first transtensional phase and Pannonian-Early Pontian during the second one) are also correlated with depositional megacycles previously defined in the CPBS. Badenian clastic, coarseand medium-grained, marine strata correspond to the first megacycle. Upper Miocene lacustrine deposits, mostly medium- and fine-grained sandstones and marls, can be correlated with the second depositional megacycle.

Acknowledgements. This work is part of a multidisciplinary research study that was performed until 2011 within the project entitled "Stratigraphical and geomathematical research of petroleum geologic systems in Croatia" (project no. 195-1951293-0237), financed by the Ministry of Science, Education and Sports of the Republic of Croatia. I am grateful to journal reviewers J. Geiger, A. Wysocka and an anonymous reviewer for their helpful comments on the earlier drafts of the paper.

\section{REFERENCES}

BÉRCZI I., HAMOR G., JAMBOR A. and SZENTGYÖRGYI K. (1988)Neogene sedimentation in Hungary. AAPG Mem., 45: 57-67.

BLAŠKOVIĆ I. (1982) - The Neogene of the Ilova River depression (Northern Croatia). Acta geol. JAZU (Prirodoslovna istraživanja 46), 12 (2): 23-67.

BLAŠKOVIĆ I., TIŠLJAR J., DRAČIČEVIĆ I. and VELIĆ J. (1984) Evolution of depositional environments of Miocene sediments on western hills of Psunj Mt. (northern Croatia) (in Croatian with English abstract). Geol. vjesnik, 37: 11-32.

BOUMA A.H. (1962) - Sedimentology of some flysch deposits: a graphic approach to facies interpretation. Elsevier Pub. Comp., Amsterdam.

BOUMA A.H. (1972) - Recent and ancient turbidites and contourites. Gulf Coast Ass. Geol. Soc., 22: 205-221.

ĆORIĆ S., PAVELIĆ D., RÖGL F., MANDIĆ O., VRABAC S., AVANIĆ R., JERKOVIĆ L. and VRANJKOVIĆ A. (2009) - Revised Middle Miocene datum for initial marine flooding of North Croatian Basins (Pannonian Basin System, Central Paratethys). Geol. Croat., 62 (1): 31-34.

HAQ B.U. and EYSINGA F.W.B., eds. (1998) - Geological Time Table, Fifth Edition (Wall Chart). Elsevier Science, Amsterdam.

HERNITZ Z. and JURAK V. (1973) - Primjena paleostrukturne i statističke analize naslaga mladeg tercijara u području Ivanić-Grada (sjeverna Hrvatska) (in Croatian). Nafta, 24 (7-8): 343-367.

KOVÁČ M., BARATH I. and NAGYMAROSY A. (1997) - The Miocene collapse of the Alpine-Carpathian-Pannonian junction - an overview. Acta Geol. Hung., 40 (3): 241-264.

LUČIĆ D., KRIZMANIĆ K. and DALIĆ N. (1995) - Lithofacies and sequence stratigraphy of Upper Miocene siliciclastic deposits in Okoli Region (Sava Depression, Croatia). Abstract book of the 1st Croatian Geological Congress (ISBN 953-96520-4-9), Opatija, October 1995. Croatian Geological Society.

MALVIĆ T. (1998) - Structural and tectonic relations in the wider area of Galovac-Pavljani Oil Field (in Croatian with English summary). MSc. thesis, Faculty of Mining, Geology and Petroleum Engineering, University of Zagreb.

MALVIĆ T. (2003) - Oil-geological relations and probability of discovering new hydrocarbon reserves in the Bjelovar Sag (in Croatian and
English). Ph.D. thesis, Faculty of Mining, Geology and Petroleum Engineering, University of Zagreb.

MALVIĆ T. (2006) - Middle Miocene depositional model in the Drava Depression described by geostatistical porosity and thickness maps (case study: Stari Gradac-Barcs Nyugat Field). Rud.-geol.-naft. zbornik, 18: 63-70.

MALVIĆ T. (2011) - Geological maps of Neogene sediments in the Bjelovar Subdepression (northern Croatia). J. Maps, 7: 304-317.

MALVIĆ T. and VELIĆ J. (2010) - Relation between effective thickness, gas production and porosity in heterogeneous reservoirs, an example from the Molve Field, Croatian Pannonian Basin. Petrol. Geosc., 16 (1): 41-51.

MALVIĆ T. and VELIĆ J. (2011) - Neogene tectonics in Croatian part of the Pannonian Basin and reflectance in hydrocarbon accumulations. In: New Frontiers in Tectonic Research: at the Midst of Plate Convergence (ed. U. Schattner): 215-238. InTech.

MALVIĆ T., VELIĆ J. and PEH Z. (2005) - Qualitative-quantitative analyses of the influence of depth and lithological composition on Lower Pontian sandstone porosity in the central part of Bjelovar Sag (Croatia). Geol. Croat., 58 (1): 73-85.

MUTTI E. and RICCI LUCCHI F. (1972) - Turbidites of the northern Apennines: introduction to facies analysis. Internat. Geol. Rev., 20: $125-166$.

NOVAK ZELENIKA K., MALVIĆ T. and GEIGER J. (2010) - Mapping of the Late Miocene sandstone facies using indicator kriging (in Croatian and English). Nafta, 61 (5): 225-233.

NOVAK ZELENIKA K. and MALVIĆ, T. (2011) - Stochastic simulations of dependent geological variables in sandstone reservoir of Neogene age: a case study of Kloštar Field, Sava Depression. Geol. Croat., 64 (2): $225-233$.

PAVELIĆ D. (2001) - Tectonostratigraphic model for the North Croatian and North Bosnian sector of the Miocene Pannonian Basin System. Basin Res., 13 (3): 359-376.

PAVELIĆ D. (2002) - The south-western boundary of Central Paratethys. Geol. Croat., 55 (1): 83-92.

RÖGL F. (1996) - Stratigraphic correlation of the Paratethys Oligocene and Miocene. Mitt. Ges. Geol. Bergbaust. Wien, 41: 65-73. 
RÖGL F. (1998) - Palaeographic consideration for Mediterranean and Paratethys Seaways (Oligocene to Miocene). Ann. Naturhist. Mus. Wien (Serie A), 99: 279-310.

RÖGL F. and STEININGER F. (1984) - Neogene Paratethys, Mediterranean and Indo-Pacific seaways. Geol. J. Spec. Issue, 11: 171-200.

ROYDEN L.H. (1988) - Late Cenozoic tectonics of the Pannonian Basin System. AAPG, Mem., 45: 27-48.

SHANMUGAM G. and MOIOLA R.J. (1985) - Submarine fan models: problems and solutions. In: Submarine Fan Related Turbidite Systems (eds. A.H. Bouma, W.R. Normark and N.E. Barnes): 29-34. Springer-Verlag, New York.

SHANMUGAM G., DAMUTH J.E. and MOIOLA R.J. (1985) - Is the turbidite facies association scheme valid for interpreting ancient submarine fan environments? Geology, 13: 234-237.

ŠĆAVNIČAR B. (1979) - Pješčenjaci pliocena i miocena Savske potoline (in Croatian). 3rd annual scientific meeting ZSN JAZU, Novi Sad, March 1977, ZSN JAZU.

TIŠLJAR J. (1993) - Sedimentary bodies and depositional models for the Miocene oil-producing areas of Ladislavci, Beničanci and Obod. Nafta, 44 (10): 531-542.

TROSKOT-ČROBIĆ T., VELIĆ J. and MALVIĆ T. (2009) - Comparison of the Middle Miocene and the Upper Miocene source rock formations in the Sava Depression (Pannonian Basin, Croatia). Geol. Croat., 62 (2): 123-133.

VELIĆ J. (2007) - Geologija ležišta nafte i plina. Faculty of Mining, Geology and Petroleum Engineering, University of Zagreb.

VELIĆ J., WEISSER M., SAFTIĆ B., VRBANAC B. and IVKOVIĆ Ž (2002) - Petroleum-geological characteristics and exploration level of the three Neogene depositional megacycles in the Croatian part of the Pannonian Basin. Nafta, 53 (6-7): 239-249.

VELIĆ J., MALVIĆ T., CVETKOVIĆ M., WEISSER M. and CURI V. (2008) - Observation useful for increase of hydrocarbon fields exploi- tation period within Croatian part of the Pannonian basin. Proc. SGEM conference "Modern Management of Mine Producing Geology and Environmental Protection". Albena, June 2008. SGEM.

VELIĆ J., MALVIĆ T., CVETKOVIĆ M. and VRBANAC B. (2010) Characteristics of hydrocarbon fields in the Croatian part of the Pannonian Basin. Oil Gas Europ. Mag., 36 (3): 146-147.

VELIĆ J., MALVIĆ T. and CVETKOVIĆ M. (2011) - Palinspastic reconstruction of synsedimentary tectonics of Neogene and Quaternary sediments in the Kloštar Field (Sava Depression, Pannonian Basin, Croatia). Z. dt. Ges. Geowiss., 162 (2): 193-201.

VRBANAC B. (1996) - Palaeostructural and sedimentological analyses of Upper Pannonian sediments Ivanić grad Formation in the Sava Depression (in Croatian with English abstract). Ph.D Thesis, Faculty of Natural Sciences, University of Zagreb.

VRBANAC B. (2002) - Facies and facies architecture of the Ivanic Grad Formation (late Pannonian) - Sava Depression, NW Croatia. Geol. Croat., 55 (1): 57-77.

VRBANAC B., VELIĆ J. and MALVIĆ T. (2010) - Sedimentation of deep-water turbidites in main and marginal basins in the SW part of the Pannonian Basin. Geol. Carpath., 61 (1): 55-69.

VRSALJKO D., PAVELIĆ D., MIKNIĆ M., BRKIĆ M., KOVAČIĆ M., HEĆIMOVIĆ I., HAJEK-TADESSE V., AVANIĆ R. and KURTANJEK N. (2006) - Middle Miocene (upper Badenian/Sarmatian) palaeoecology and evolution of the environments in the area of Medvednica Mt. (North Croatia). Geol. Croat., 59 (1): 51-63.

WALKER R.G. (1978) - Deep-water sandstone facies and ancient submarine fans: Models for exploration for stratigraphic traps. AAPG Bull., 62: 932-966.

YILMAZ P.O., NORTON J.O., LEARY A.N.D. and CHURCHLA R.J. (1996) - Tectonic evolution and paleogeography of Europe. Mus. Nat. Hist. Paris, Mém., 170: 46-67. 